J. clin. Path. (1948), 1, 269.

\title{
THE ERRORS OF SOME HAEMATOLOGICAL METHODS AS THEY ARE USED IN A ROUTINE LABORATORY
}

\author{
BY \\ ROSEMARY BIGGS AND R. L. MACMILLAN \\ From the Department of Pathology, The Radcliffe Infirmary, Oxford
}

(RECEIVED FOR PUBlication, JUNE 25, 1948)

The quantitative measurements made in a haematological laboratory assess the magnitude of deviations from the normal, and successive read: ings indicate either the response to treatment or the natural progress of the disease. These figures can be of little value unless the range of chance variation that several laboratory workers may record in one blood sample is less than the difference that the clinician requires to distinguish. It has been usual for the standard of precis on of a method to be set by one expert, whose results, while measuring the minimum error, may bear little relation to ordinary routine practice. In the present study an attempt was made to assess the errors of some common haematological methods as they are used as a routine in laboratories. Those taking part in the experiments were laboratory technicians and doctors of average skill, who carried out the investigations carefuliy; any gross technical inaccuracies" can be excluded. It was hoped that the experiments might suggest which techniques were likely to give the most generally reliable results. The methods studied were: haemoglobin estimation, red cell count, and haematocrit, from which the errors of the colour index, mean corpuscular vo'ume, and mean corpuscular haemoglobin concentration could be calculated. Other methods included were the mean cell diameter derived from the Price-Jones curve, reticulocyte count, p'atelet count, whole blood coagulation, and red cell fragility. The white cell count was not considered because, since the work of Berkson and others $(1935,1940)$ it is widely recognized that this investigation has a large error.
Technique*

Red cell counts.-These were made by diluting the b'ood in Haye.n's fluid to 1/200 and counting eighty small squares in a Neubauer counting-chamber.

Haemoglobin.-This was estimated by two methods :

1. The Haldane method, using a standard calibrated by the National Physical Laboratory. The tubes were matched against a uniformly illuminated screen. $14.7 \mathrm{~g}$. haemoglobin were taken to represent 100 per cent (King and others, 1947).

2. A neutral grey photometer method using an instrument designed by Duffie (1945). In this method $0.02 \mathrm{ml}$. of blood was pipetted into approximately $2 \mathrm{ml}$. of distilled water in a cylindrical tube of standard diameter. The oxyhaemoglobin content was measured in terms of the optical density of the solution in comparison with a neutral grey wedge calibrated in grammes of haemoglobin, $14.7 \mathrm{~g}$. being taken to represent 100 per cent.

Packed cell volume.-This was measured in Wintrobe's tubes, using oxalated venous blood in which the proportion of oxalate recommended by Wintrobe (1946) was used.

Price-Jones curves.-These were constructed using a projecting microscope and a high-power objective in a dry system giving a magnification on the screen of 2,000 . The cells were measured directly, and each mean cell diameter was recorded with no preliminary outlining in pencil.

Platelets.-Platelets were counted by two methods :

1. Dameshek's method (1932). In this method the platelets in capillary blood, stained with brilliant

\footnotetext{
* The determinations of red cell count, haemoglobin, jacked cell volume, and mean cell diame:er were made fiom the same oxalated venous blood sample. Tre reticulocyte counts and platelet counts were made from capillary blood.
} 
ROSEMARY BIGGS AND R. L. MACMILLAN

\begin{tabular}{|c|c|c|c|c|c|c|c|c|c|c|c|}
\hline 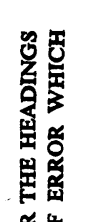 & 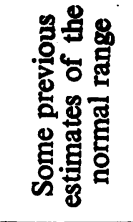 & 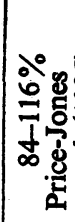 & & 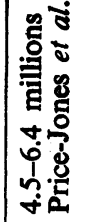 & & & & 5 & $\begin{array}{l}\stackrel{2}{0} \\
\stackrel{0}{1} \\
\underline{1} \\
\end{array}$ & & \\
\hline 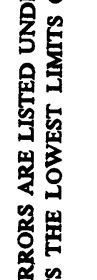 & 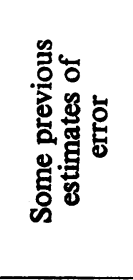 & 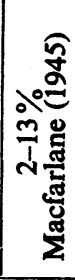 & 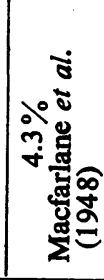 & 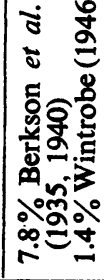 & 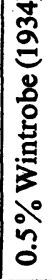 & 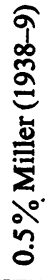 & & & 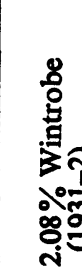 & & 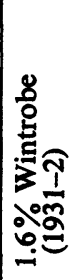 \\
\hline 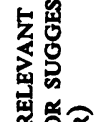 & 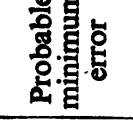 & aे & 离 & 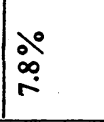 & 윰 & 离 & $\stackrel{\circ}{\circ}$ & $\frac{\circ}{0}$ & 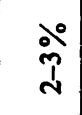 & 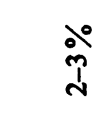 & $\frac{a 0}{a}$ \\
\hline 递 & 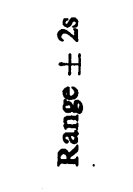 & $\frac{\stackrel{0}{0}}{0}$ & $\frac{\stackrel{0}{0}}{\frac{0}{0}}$ & 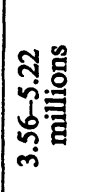 & 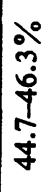 & 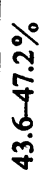 & 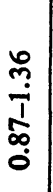 & $\begin{array}{l}\stackrel{5}{+} \\
\stackrel{5}{0} \\
\text { o }\end{array}$ & 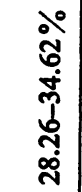 & 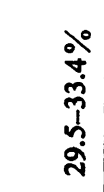 & 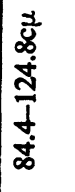 \\
\hline 等 & 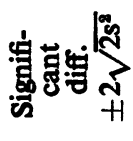 & $\mid \begin{array}{l}\stackrel{0}{0} \\
\dot{+} \\
\dot{\Xi}\end{array}$ & 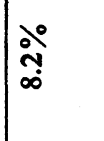 & 望 & $\stackrel{\circ}{ٍ}$ & 芦 & 商 & 롱 & $\begin{array}{l}\stackrel{2}{\circ} \\
\stackrel{+}{+}\end{array}$ & 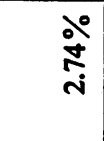 & 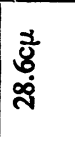 \\
\hline 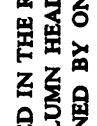 & 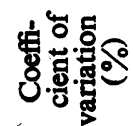 & นี & $\mid \begin{array}{r}\dot{m} \\
\end{array}$ & $a_{\alpha}^{n}$ & $\stackrel{0}{-}$ & $\stackrel{\circ}{i}$ & $\hat{0}$ & aे & $\stackrel{\circ}{\dot{n}}$ & $\vec{m}$ & \%ْ \\
\hline 思 & 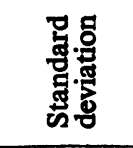 & $\stackrel{\circ 0}{\bar{n}}$ & 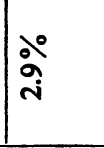 & 旾高 & 辛 & 犬̊ํे & $\stackrel{?}{0}$ & $\overline{0}$ & ڤั̊ & 蒿 & $\frac{x}{0}$ \\
\hline 8 & $\frac{\sqrt{5}}{\Sigma}$ & a & ڤ̊ & 它产 & 离 & 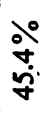 & $\stackrel{\simeq}{=}$ & $\cong$ & 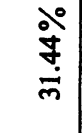 & $\frac{\stackrel{d}{+}}{\stackrel{m}{m}}$ & $\begin{array}{l}0 \\
0 \\
0 \\
0 \\
0\end{array}$ \\
\hline 记 & 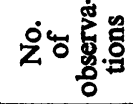 & \& & in & 8 & ஜ & శి & ஜ & ஜ & 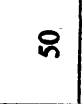 & 8 & $\stackrel{8}{n}$ \\
\hline 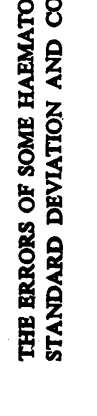 & 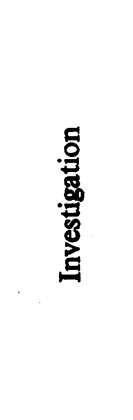 & 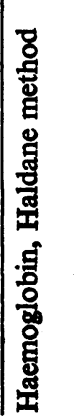 & 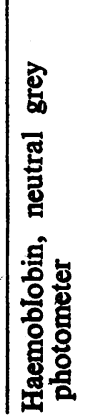 & 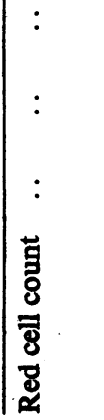 & 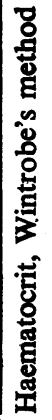 & 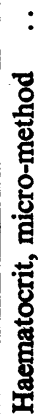 & 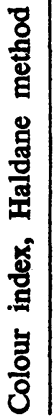 & 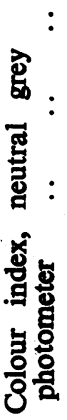 & 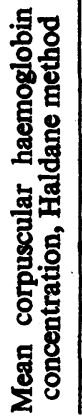 & 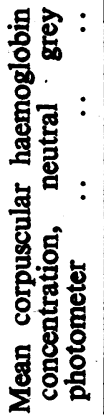 & 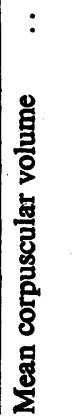 \\
\hline
\end{tabular}




\begin{tabular}{|c|c|c|c|c|c|c|c|c|c|c|c|}
\hline 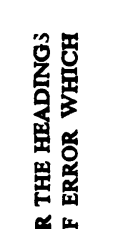 & 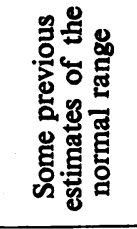 & & 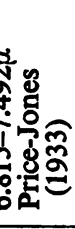 & & & & & & & & \\
\hline 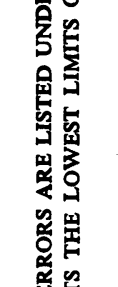 & 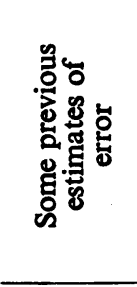 & & 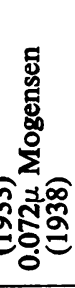 & & & 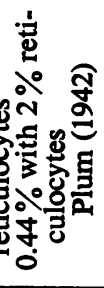 & 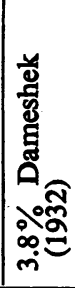 & 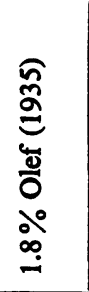 & & & \\
\hline 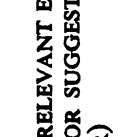 & 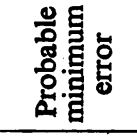 & $\overbrace{0}^{2}$ & $5_{0}^{2}$ & & & & $\mid \begin{array}{l}00 \\
\frac{1}{1} \\
0\end{array}$ & |⿺辶̀ & & & \\
\hline 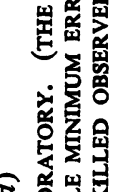 & 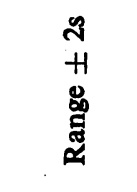 & $\begin{array}{l}0 \\
\hat{0} \\
\hat{0} \\
0 \\
0\end{array}$ & 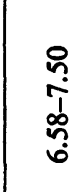 & 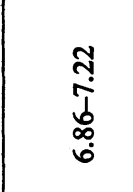 & 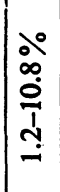 & do & 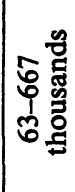 & 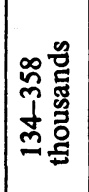 & 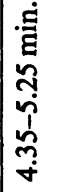 & 疍 & 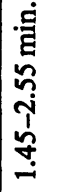 \\
\hline 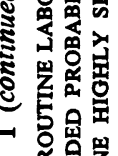 & 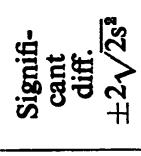 & 䓂 & 苦 & 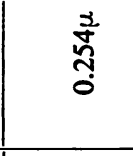 & $\mid \begin{array}{l}00 \\
\infty \\
0 \\
0\end{array}$ & 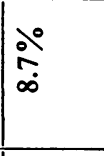 & 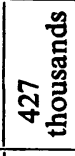 & 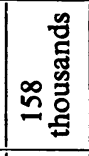 & 蒙 & 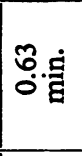 & 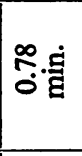 \\
\hline 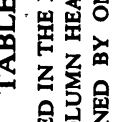 & 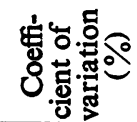 & $\stackrel{m}{m}$ & 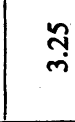 & 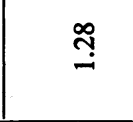 & $q$ & $\%$ & $F$ & $\approx$ & f & ֶָ & $\stackrel{\infty}{m}$ \\
\hline 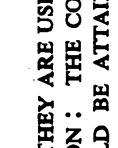 & 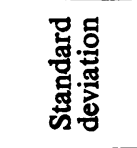 & $\frac{3}{\sqrt[n]{3}}$ & స్్ํ & ${ }_{0}^{3}$ & $\mid \begin{array}{l}\stackrel{0}{0} \\
\stackrel{+}{+}\end{array}$ & $\frac{\partial 0}{\dot{m}}$ & 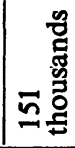 & 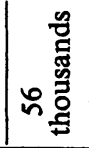 & సั. & 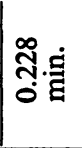 & సે̊.: \\
\hline 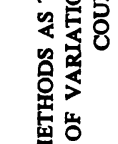 & $\sum_{\Sigma}^{\text {ङ }}$ & مِ & & & ㅇํㅇ & ঐ̊ & 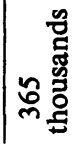 & 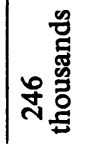 & $\mid \stackrel{\infty}{+} \cdot \dot{\square}$ & 垸 & 열. \\
\hline 氞意 & 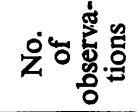 & $\approx$ & 它苞 & 完总 & $\stackrel{\infty}{=}$ & $\stackrel{\infty}{\stackrel{\infty}{2}}$ & $\approx$ & $\succsim$ & $q$ & q & q \\
\hline 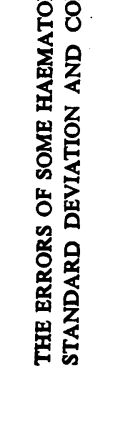 & 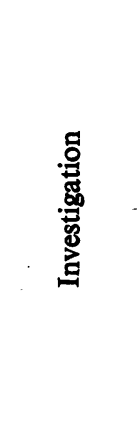 & 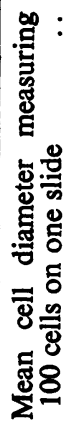 & 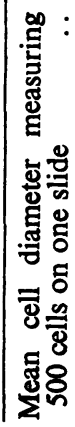 & 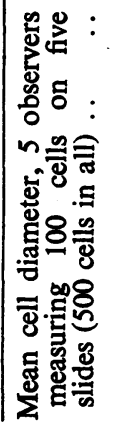 & 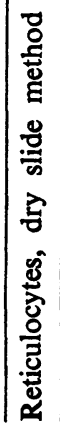 & 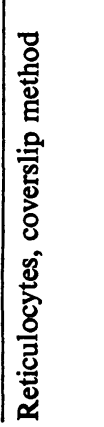 & 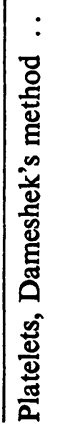 & 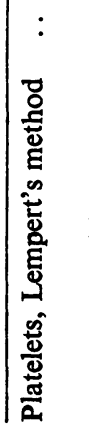 & 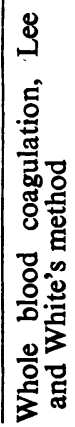 & 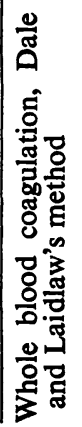 & 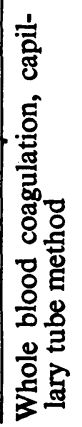 \\
\hline
\end{tabular}


cresyl blue, are counted with an oil immersion objective in relation to 1,000 red cells and the total number of platelets are assessed from a separate red cell count.

2. Lempert's (1935) modification of Kristenson's method. In this method the plate'ets are counted directly in a counting chamber after dilution to $1 / 20$ with a freshly prepared solution containing brilliant cresyl blue to render the platelets more readily visible, and urea to haemolyse the red cel's.

Percentage of reticulocytes.-The counts were made by two methods :

1. A drop of a saturated solution of brilliant cresyl blue in alcohol was allowed to dry on a perfectly clean slide, and a small drop of capillary blood collected on a clean coverslip was inverted over the dye to form a very thin film. The preparations were allowed to stand for half an hour for staining to occur.

2. Five drops of a mixture of one part of a saturated solution of brilliant cresyl b.ue in alcohol, and 4 parts 1.0 per cent sodium citrate in normal saline were placed in a small tube. To this was added one drop of blood. If these proportions are carefully observed the red ce'ls will not crenate. The tubes were shaken and allowed to stand for twenty minutes at $37^{\circ} \mathrm{C}$. The contents of the tubes were then thoroughly mixed, and films made on clean slides were stained with Leishman's stain. In both methods the reticulocytes were clearly visible, but in the coverslip method it was not always easy to prepare films in which the red cells were sufficiently separated for them to be counted with accuracy.

Whole blood coagulation.-This was measured by three methods:

1. Lee and White (1913). Venous blood was collected in a paraffined syringe and $1 \mathrm{ml}$. placed in each of four small test tubes of uniform bore which were kept at $37^{\circ} \mathrm{C}$. The coagulation time was measured from the time of filling the syringe.

2. Dale and Laidlaw (1911-12). Small tubes of wide capillary bore, each containing a freely mobile lead shot, were prepared. These were rapidly filled with capillary blood and, held by forceps, were immersed in water at $37^{\circ} \mathrm{C}$. The tube was inverted at intervals and the time at which the lead shot failed to move was recorded.

3. Capillary blood was taken into a number of fine capillary tubes, the ends of which were then sealed with plasticine. The tubes were kept at $37^{\circ} \mathrm{C}$. Pieces of tubing were broken off at intervals until a clot was withdrawn (Sabràzes, 1904).

Red-cell fragility. - This was measured by a method similar to that of Dacie and Vaughan (1938). The saline dilutions differing by 0.02 per cent were made up individually from sodium chloride dried to a constant weight, and each was tested with a standard silver nitrate solution. Heparin was used as anticoagulant, the volume of plasma was adiusted to a normal haematocrit reading, and the blood was oxygenated immediately before use. In the original technique the b:ood was added to $1 \mathrm{ml}$. of each saline dilution from a dropping pipette; in this experiment $0.02 \mathrm{ml}$. amounts were measured with a series of haemoglobin pipettes. After the tubes had stood in the refrigerator the degree of haemolysis was read against a set of dilutions from comp.etely haemolysed blood made from each sample tested.

\section{Results}

The total errors for the methods studied, in terms of their standard deviations and coefficients of variations, are shown in Table $I$.

The experiments were planned to separate by analysis of variance those components of error likely to be of importance in routine practice. Thus, for example in the red cell count, errors due to pipettes and counting-chambers and to differences between observers could be calculated. In whole-blood coaguation on the other hand, where observers are unlikely to disagree, differences between the order of taking the samples on one day and between samples taken on separate days were measured.

The component errcrs $\left(S_{1}, S_{2}, S_{3} \ldots\right)$ are related to the total standard deviation $\left(S_{T}\right)$ by the formula :

$$
\mathrm{S}_{\mathrm{T}}{ }^{2}=\mathrm{S}_{1}{ }^{2}+\mathrm{S}_{2}{ }^{2}+\mathrm{S}_{3}{ }^{2} \text { (Formula 1) }
$$

Any part of the total error not attributed to a specific factor was classed as random variation.

Haemoglobin.-The errors inherent in estimating haemoglobin have been worked out with considerable care by Macfarlane (1945) and Macfarlane and others (1948). Our results confirm these more detailed observations.

In this experiment five observers each made ten readings both by the Haldane method and with the neutral grey photometer, using ten pipettes and a single sample of oxalated blood. From an analysis of variance the errors referable to the observers and the calibration of the pipettes could be calculated. In addition the components of error due to reading the neutral grey photometer, the calibration, and the filling of the pipettes were determined in a series of separate experiments. The error of reading the photometer was measured by making twenty readings from one diluted sample of blood. The error caused by inaccuracy in filling the pipettes combined with the error of reading the photometer was estimated by filling one pipette ten times and reading the results on the photometer. The error due to calibration of pipettes together with those due to filling and to reading the photometer was assessed by filling ten different pipettes and reading the results on the photometer. From these observations the component errors could be calculated, using Formula (1). 


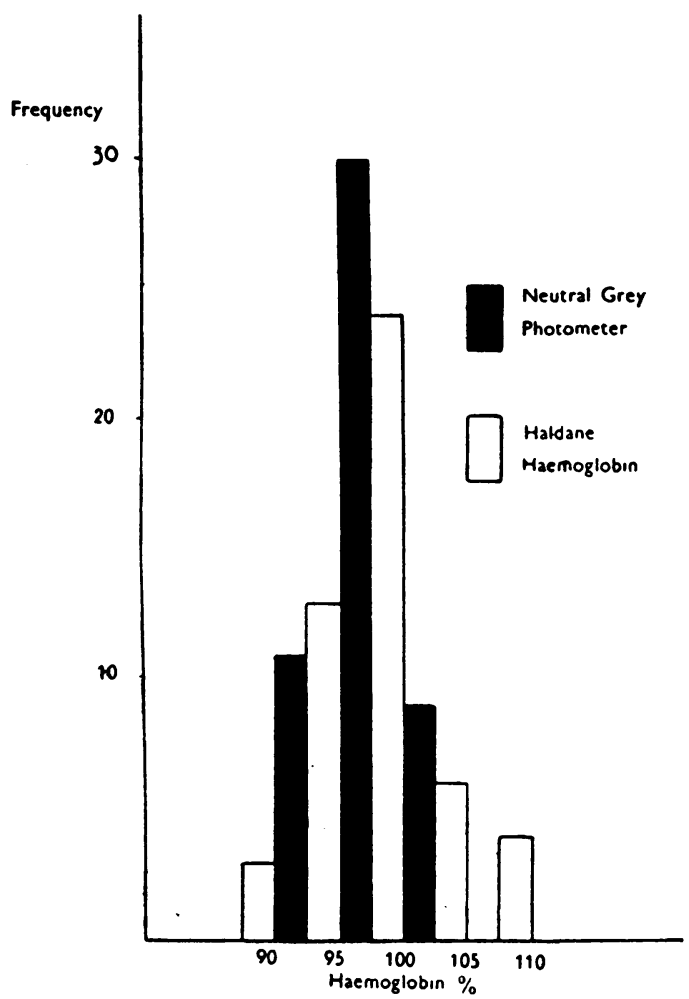

FIG. 1.-Histogram to show the distribution of individual readings for haemoglobin estimation by the Haldane method and using a neutral grey photometer. With each method five observers made ten estimations on one sample of venous blood using ten pipettes.

Fig. 1 shows the distribution of the different values for the haemoglobin obtained by the five observers. In the Haldane method there was a wider dispersion of the readings than was shown by the neutral-grey photometer. In Tab'e II the errors for the two methods obtained by analysis of variance are compared with each other and with those derived from the separate experiments. It will be seen that the greater precision of the neutral-grey photometer results from a reduction in both random variation and the differences between observers.* In addition it will be seen that the random error of the analysis of variance for the photometer method, which necessarily includes that of filling pipettes, is entirely accounted for by this error, which was determined separately. Since the error of the observers and of reading the photometer are both of the order of 1 per cent, the error of the photometer method is probably

\footnotetext{
- Since only five observers took part in the majority of the experiments described, the observer component is seldom determined with great precision.
}

approaching the minimum for haemoglobin determination.

Red cell count.-The error of the red cell count has been the subject of much controversy. On the one hand Berkson and others $(1935,1940)$ have shown that the minimum error is of the order of 7.8 per cent, whereas other workers believe that far greater uniformity is possible. Wintrobe (1946) stated: "In spite of the fact that statistical analysis indicates that the error in counting red cells may be as great as 16 per cent even in the hands of trained technicians, it will be found that, with practice, counts agreeing within 200,000 cells per c.mm. can be made." Our results have favoured Berkson and others' estimate of the error, but it is also true that trained technicians can make counts that will agree within 200,000 cells. However, this uniformity cannot be maintained if several skilled workers each make a series of independent counts. It will then be found that their mean values differ more widely than would be expected from chance variation (Biggs and MacMillan, p. 288 of this issue). The "accuracy" of the skilled haematological technician is a product of the method of training. It is usual to set a standard of agreement between repeat counts which must be achieved before a worker's results are considered reliable. Since this standard is invariably one that cannot be reached by accurate

\section{TABLE II}

THE COMPONENTS OF ERROR IN HAEMOGLOBIN ESTIMATION EXPRESSED AS A PERCENTAGE OF THE MEAN HAEMOGLOBIN VALUES: BASED ON FIFTY OBSERVATIONS MADE BY FIVE OBSERVERS ON A SINGLE SAMPLE OF BLOOD

\begin{tabular}{|c|c|c|c|}
\hline $\begin{array}{l}\text { Source of error } \\
\text { and mean value }\end{array}$ & $\begin{array}{c}\text { Estimation } \\
\text { of error by } \\
\text { separate } \\
\text { experiments } \\
(\%)\end{array}$ & $\begin{array}{c}\text { Analysis of } \\
\text { variance in } \\
\text { the neutral } \\
\text { grey photo- } \\
\text { meter method } \\
(\%)\end{array}$ & $\begin{array}{c}\text { Analysis } \\
\text { of vari- } \\
\text { ance for } \\
\text { Haldane } \\
\text { method } \\
(\%)\end{array}$ \\
\hline Mean & 97 & 97 & 97 \\
\hline Total error ... & $3.3^{*}$ & 3.0 & 5.2 \\
\hline $\begin{array}{cc}\text { Calibration of } \\
\text { pipettes }\end{array}$ & 2.0 & 1.8 & 2.4 \\
\hline Filling pipettes & 2.2 & & \\
\hline Observers $\quad$. & & 1.0 & 2.8 \\
\hline $\begin{array}{l}\text { Reading photo- } \\
\text { meter }\end{array}$ & 1.38 & & \\
\hline Random error & & 2.2 & 3.7 \\
\hline
\end{tabular}

* Excluding the observer component. 
counting, the technician learns to count very rapidly and to make continuous unconscious adjustment in a series of counts to ensure that all will agree with the first.

In this experiment five observers made ten red cell counts from the sample of blood used in the haemoglobin determinations, using ten pipettes and ten counting chambers. One red cell pipette was always used with the same counting chamber, and thus the errors due to these two factors were estimated together.

It will be seen from Fig. 2 that the total range of variation was very large, rather larger than that

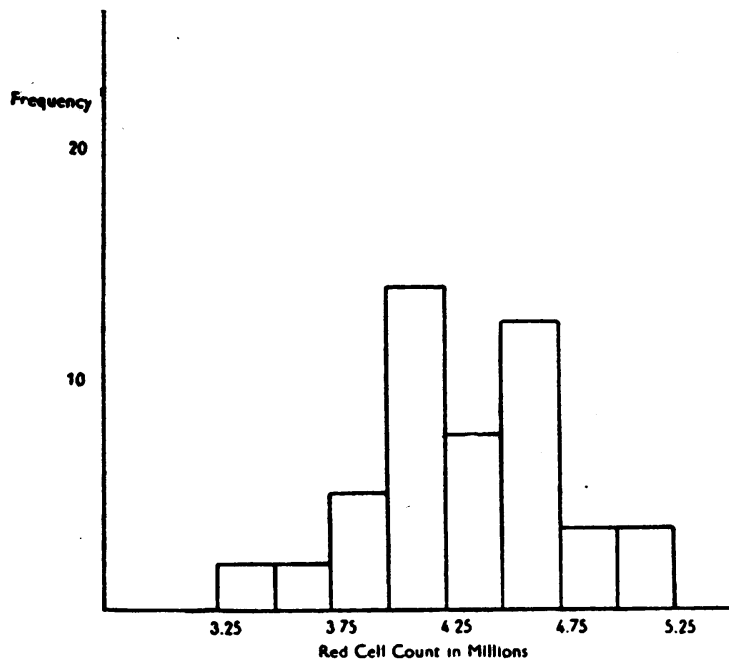

FIG. 2.-Histogram to show the distribution of individual red cell counts. Five observers each made ten estimations from the sample of blood from which the haemoglobin determinations were made, using ten pipettes and ten counting chambers. Each pipette was always used with the same counting chamber.

recorded by Berkson and others. This increase in error is due both to the inclusion of different observers in the experiment and to the fact that, whereas Berkson and others counted the red cells with an electric counter from photographs, in these experiments the cells were counted by eye. In addition it will be seen from Table III that the component errors are rather different. Berkson and others record a larger error for pipettes and counting chambers, while our resuits show a greater random fluctuation. This discrepancy is due to the different methods used to discover the errors. Berkson and others made a series of separate experiments similar to those described for the errors of the haemoglobin pipette and reading the neutral-grey photometer, while our results were
TABLE III

THE COMPONENTS OF ERROR IN RED CELL COUNTING EXPRESSED AS A PERCENTAGE OF THE MEAN VALUES FOR THE RED CELL COUNT. THE RESULTS OF OUR EXPERIMENTS COMPARED WITH THOSE OF BERKSON AND OTHERS (1940)

\begin{tabular}{|c|c|c|}
\hline $\begin{array}{l}\text { Source of error } \\
\text { and mean value }\end{array}$ & $\begin{array}{l}\text { Results from } \\
\text { analysis of vari- } \\
\text { ance in our } \\
\text { experiments }\end{array}$ & $\begin{array}{l}\text { Results of Berk-; } \\
\text { son and others' } \\
\text { experiments }\end{array}$ \\
\hline Mean value & $\begin{array}{c}4.39 \\
\text { millions per } \\
\text { c. } \mathrm{mm} \text {. }\end{array}$ & \\
\hline Total error & $9.46 \%$ & $7.8 \% *$ \\
\hline Pipettes .. & \multirow{2}{*}{$4.26 \%$} & $4.7 \%$ \\
\hline Counting chambers & & $4.6 \%$ \\
\hline Observers .. & $3.12 \%$ & \\
\hline Random error & $7.8 \%$ & $4.2 \%$ \\
\hline
\end{tabular}

obtained by analysis of variance. The figure for random error in our calculations includes the errow of filling the pipettes, which was estimated separately by Berkson and others.

The variability of this method, from which repeated counts on the same sample may be equivalent to differences of more than $1,000,000$ cells per c.mm. in a 5,000,000 count indicates that small changes in red cell count cannot be measured with reasonable precision.

Packed cell volume.-A previous experiment in which Wintrobe (1934) estimated the error of the haematocrit as 0.5 per cent suggests that this method should give uniform results.

In this experiment each of the five observers filled ten Wintrobe haematocrit tubes with blood from the sample used in the red cell counts and haemoglobin determinations. These were then centrifuged at 3,000 r.p.m. for half an hour. There were no differences to be detected between the tubes. The only error was a small random fluctua- o tion of 0.5 per cent, giving a coefficient of variation of 1 per cent. This method has an almost negligible error and since some of the techniques $\omega$ applicable to capillary blood are also reliable (Miller, 1938-39) the method is well adapted to 0 routine use. The error of a capillary method in use in this laboratory is shown in Table $I$.

Indices.-The red cell counts, the determinations of haemoglobin, and the packed cell volume were all made on the same sample of blood, and since the relations between the haemoglobin and 


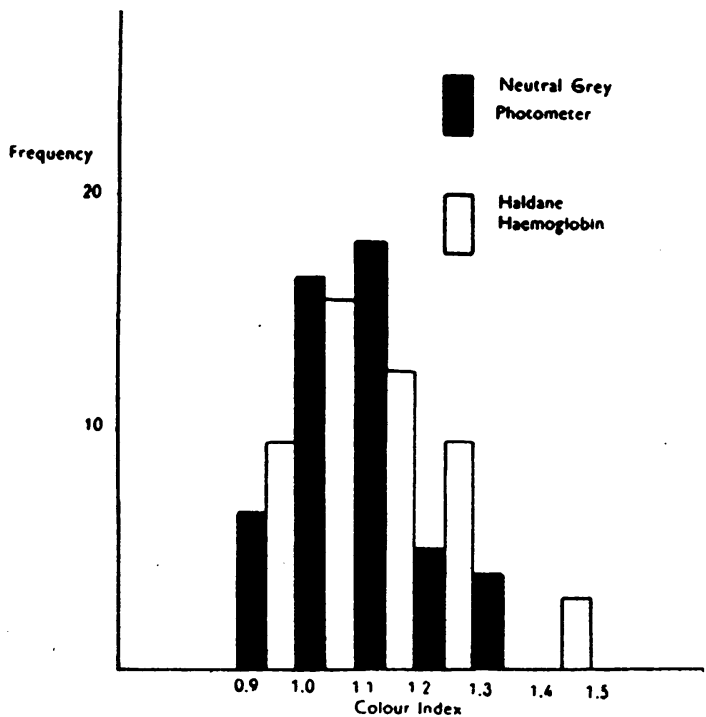

FIG. 3.-Histogram to show the distribution of the calculated values for the colour index using both the Haldane and neutral grey photometer methods. Each haemoglobin estimation was paired at random with a red cell count made by the same observer.

red cell count, the haematocrit and red cell count, and the haematocrit and haemoglobin for normal blood can all be represented by linear regression lines passing through the origin, the errors may be calculated with sufficient accuracy by pairing appropriate values at random and determining the standard deviations of the resulting indices.

The magnitudes of these errors are given in Table I, and the distribution of the individual observations in Figs. 3 to 5 . It is obvious that the indices derived from variable observations are unlikely to measure small differences reliably, but the wide range of the colour index and mean corpuscular volume is illuminating. By chance the sample of blood examined gave mean values for the colour index and mean corpuscular volume which are at the upper limit of the normal range 1.12 and $104.6 \mu$ respectively. It will be seen that in a blood sample of this type, encountered not infrequently in routine work, there is a high probability of recording a grossly pathological value. The fact that these exaggerated figures seldom reach the clinician may be attributed to the natural prejudice of technicians and pathologists in favour of reasonable results; a prejudice which leads to the repetition of values incompatible with the appearance of the blood film or grossly different from previous observations on the same patient.

Both of these indices are used to measure differences that are small in relation to their' range of chance fluctuation. Neither is therefore of great value as a single observation, though successive readings will give a general impression of any systematic trend over a period of time, such, for example, as may occur during the treatment of pernicious anaemia.

On the other hand the mean corpuscular haemoglobin concentrations showed relatively little variation, and this index, which is well adapted to the study of iron deficiency, could be used more frequently as a routine estimation.

Mean cell diameter derived from the Price-Jones curve.-Both Price-Jones (1933) and Mogensen (1938) have studied the errors inherent in drawing a Price-Jones curve, including the variation in cell size in one subject on repeated measurements from different slides, and the range in normal subjects (Price-Jones, 1933). The error in making repeated observations on one subject was small, but it is usually believed that the technique, in addition to being extremely time-consuming, is of little value except in the hands. of highly skilled and experienced observers. Our experiment was undertaken to discover whether relatively unskilled workers could obtain information of any clinical value. Five observers measured a hundred cells from each of five slides taken from the same subject at the same time. The errors referable to differences between observers and those between slides could therefore be calculated.

It will be seen in Fig. 6 that a wide variation occurred. The range of cell size in any one estimation (the standard deviation of one Price-Jones

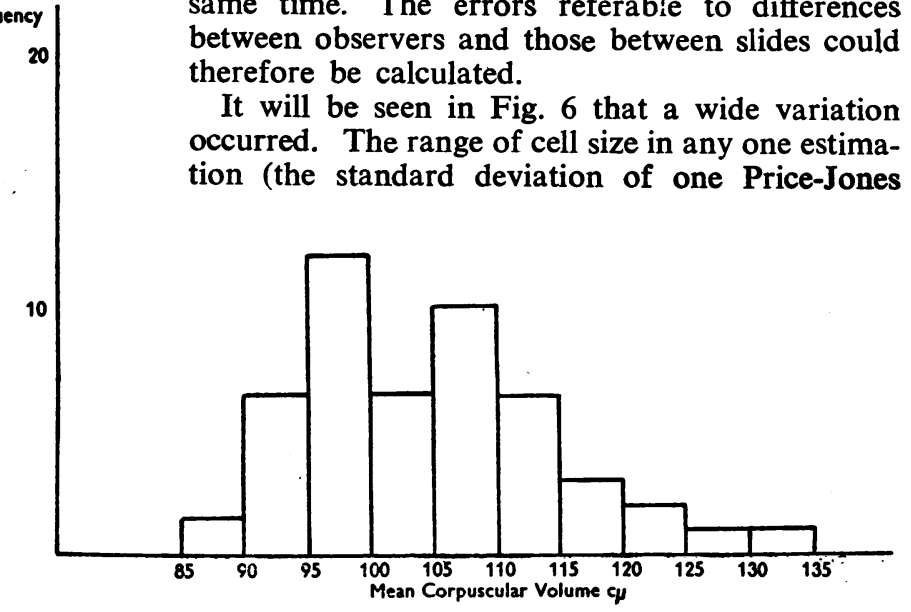

Fig. 4.-Histogram to show the distribution of the calculated values for the mean corpuscular volume. Each of the red cell counts was paired at random with a haematocrit reading made by the same observer. 


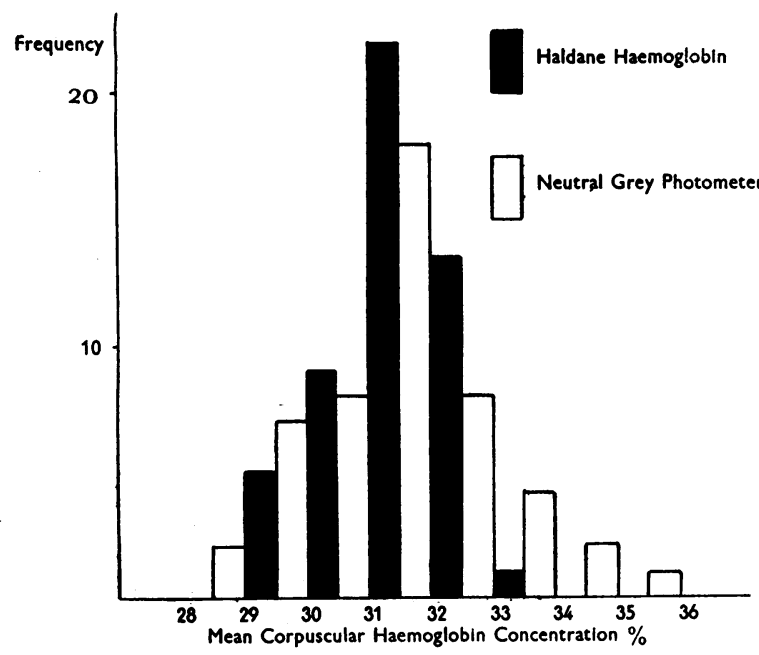

Fig. 5.-Histogram to show the distribution of the calculated values for the mean corpuscular haemoglobin concentration using both the Haldane and neutral grey photometer methods for haemoglobin determination. Each haemoglobin determination was paired at random with a haematocrit reading made by the same observer.

curve) was similar to those of Mogensen and Price-Jones and remained fairly constant throughout. The variation between different slides was also similar to those found by Mogensen and Price-Jones (Table IV). The increased error was due to differences between observers and a component classed as "interaction." Neither Mogensen nor Price-Jones considered the possibility that

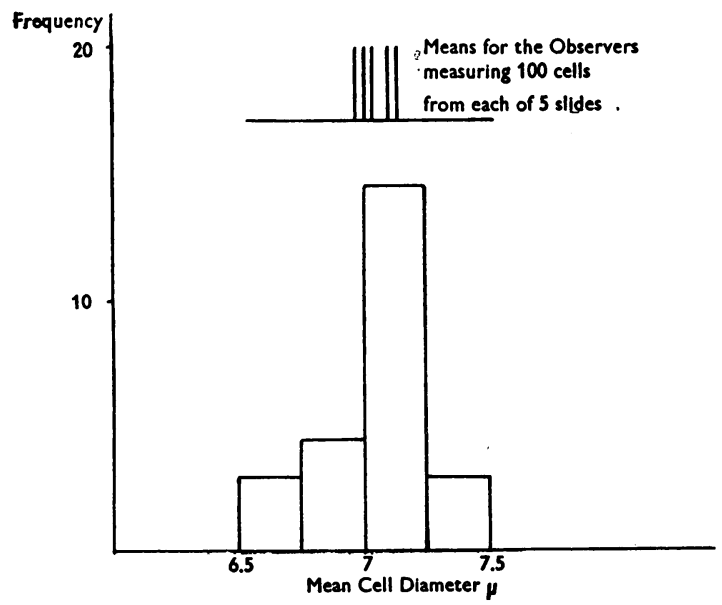

FIG. 6.-Histogram to show the distribution of individual determinations of the mean cell diameter. Five observers measured one hundred cells from each of five slides. The mean values for each observer measuring one hundred cells from the five different slides are shown above.

\section{TABLE IV}

THE COMPONENT ERRORS OF DETERMINING THE MEAN CELL DIAMETER FROM PRICE-JONES' CURVE EXPRESSED AS STANDARD DEVIATION IN $\mu$. THE RESULTS OF OUR EXPERIMENTS COMPARED WITH THOSE OF MOGENSEN (1938) AND PRICE-JONES (1933)

\begin{tabular}{|c|c|c|c|}
\hline $\begin{array}{l}\text { Source of } \\
\text { error and } \\
\text { mean value }\end{array}$ & $\begin{array}{l}\text { Error } \\
\text { deter- } \\
\text { mined } \\
\text { from our } \\
\text { experi- } \\
\text { ments }\end{array}$ & $\begin{array}{c}\text { Error } \\
\text { assessed } \\
\text { by } \\
\text { Mogensen }\end{array}$ & $\begin{array}{c}\text { Error } \\
\text { assessed } \\
\text { by } \\
\text { Price- } \\
\text { Jones }\end{array}$ \\
\hline Mean $\quad . . \quad \ldots$ & 7.04 & 7.44 & 7.328 \\
\hline Total error & 0.231 & & \\
\hline $\begin{array}{l}\text { Error for } 1 \text { observer } \\
\text { measuring } 100 \text { cells } \\
\text { on one slide }\end{array}$ & 0.143 & 0.0721 & 0.0735 \\
\hline $\begin{array}{l}\text { Differences between } \\
\text { observers }\end{array}$ & 0.171 & & \\
\hline $\begin{array}{l}\text { Differences between } \\
\text { slides } \quad . .\end{array}$ & 0.08 & 0.06 & 0.06 \\
\hline $\begin{array}{l}\text { Error component } \\
\text { classed as "inter- } \\
\text { action" } . .\end{array}$ & 0.1265 & & \\
\hline $\begin{array}{l}\text { Random error per } \\
\text { mean of } 100 \text { cells }\end{array}$ & 0.044 & 0.045 & 0.048 \\
\hline
\end{tabular}

observers might not always agree, a factor of importance in clinical practice.

As was suggested by Mogensen (1938), and more recently by Humble and Belyavin (1948), the only error reduced by increasing the number of cells measured is that due to chance variation in the population of cells selected from a particular slide. In our estimations this error was $0.04 \mu$ which, compared with a total error of $0.231 \mu$, is negligible, and no appreciably greater precision results from increasing the number of cells measured to 500 (Table I). On the other hand, if the larger errors due to the slides and observers were reduced, the precision would be increased. This can be effected if, for example, five observers each measure a hundred cells from different slides. Since only five hundred cells are measured by the five observers together, there is no increase in the total labour of Price-Jones' original technique ; in this way the error is reduced from 0.231 to $0.09 \mu$. In Fig. 6 the mean values for the five observers' measurements on different slides are compared with the total invariability. Although the error of the mean cell diameter is reduced by this method, a false impression of anisocytosis will follow 
systematic differences between observers. This may be avoided if the Price-Jones curve is constructed from the results of one observer.

The error is large compared with those of PriceJones and Mogensen, but it is small in comparison with those of other investigations that give any indication of cell size (Mean Corpuscular Volume and Colour Index). In addition the Price-Jones curve gives a valuable record of anisocytosis. Again, if highly reproducible results are required, the method by which five observers make measurements on five slides will give a precision approaching that of the experts, even including the observer component. Thus from the view point of precision the Price-Jones curve, even when constructed by the average laboratory worker, will give information of clinical value. The main disadvantage that remains is the length of time occupied by a single observation. However, we did not find that this was excessive. In forty-five minutes one observer may make all necessary measurements and complete the calculations, using a simplified technique such as that described by Humble and Belyavin (1948); no doubt this time

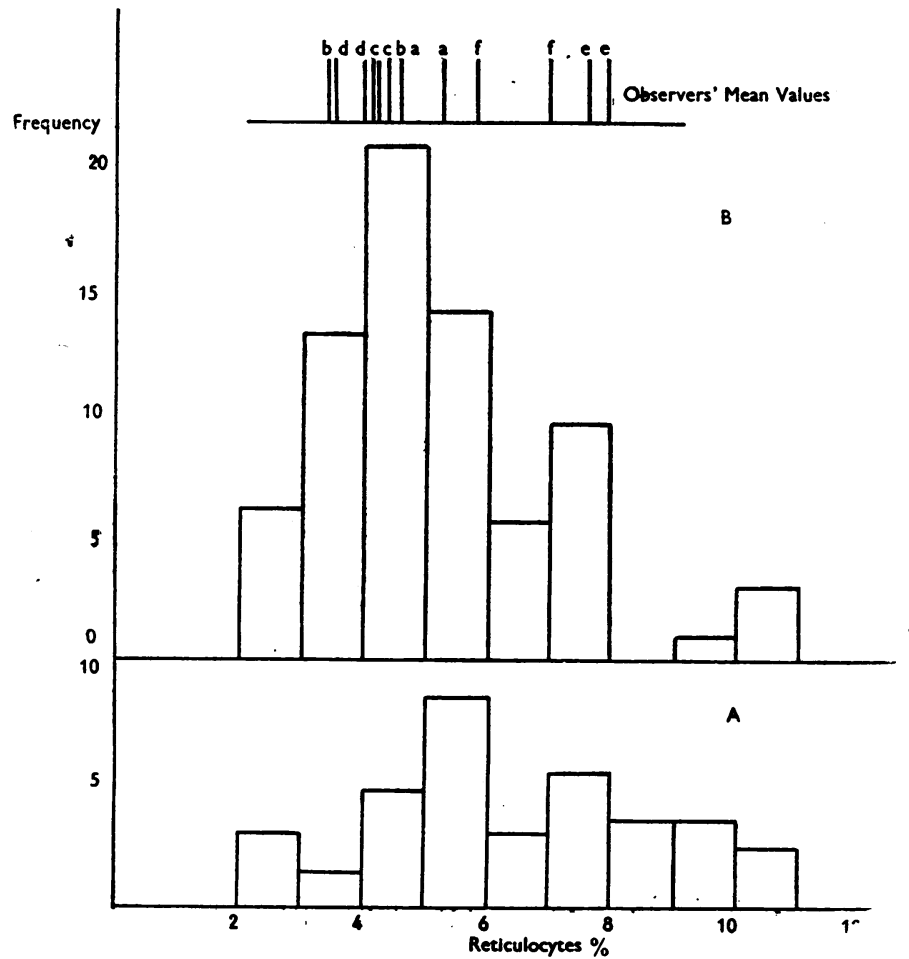

Fig. 7.-Histograms to show the distributions of the individual reticulocyte counts. The two parts of the diagram refer to different experiments (see text). In Fig. 7b the mean values obtained by the observers by the two methods of counting are indicated. could be reduced still further. Thus, if, in a case of pernicious anaemia for example, instead of making repeated observations of the Colour Index and Mean Corpuscular Volume, two Price-Jones curves were drawn, one before and the other following treatment, there would be little total loss of time, and the record of the patient's progress would be more complete and more precisely assessed.

Reticulocyte count.-Plum (1942) and Jacobsen and others (1947) have shown that repeated reticulocyte counts on one sample of blood will agree closely. It is, perhaps, difficult to understand why the errors which they record appear rather smaller than the random selection of 1,000 cells from a binomial distribution would allow. Nevertheless, even acknowledging the full standard deviation to be expected, which is of the order of 1 per cent of reticulocytes for counts from 5 to 10 per cent, it might be hoped that this would prove one of the more reliable routine methods.

In this experiment nine observers counted the number of reticulocytes in five hundred red cells from one sample of venous blood. They made two preparations by each of the methods, and thus made four counts in all. In this way any difference between the observers and between the two methods could be measured. No consistent difference between the methods was found.

From Fig. $7 \mathrm{a}$ it will be seen that a large range of variation occurred, very much larger than should result from random selection from a binominal distribution. In both methods there was a considerable difference between the results of different observers (Table V). In the coverslip method there was also a big random error, probably caused by difficulty in accurate counting on films in which the cells were not well separated. In the slide method the two counts made by each observer agreed fairly well and thus the random error was sma:1. Of these two, the slide method was therefore preferable.

The large observer error was, however, surprising, and an experiment was designed to decide whether this was due to differences between the preparations made by the observers or to difficulty in the recognition of reticulocytes. Six experienced 
TABLE V

THE COMPONENT ERRORS OF THE RETICULOCYTE COUNT EXPRESSED AS STANDARD DEVIATION IN PERCENTAGE OF RETICULOCYTE

\begin{tabular}{|c|c|c|}
\hline $\begin{array}{l}\text { Source of error and } \\
\text { mean value }\end{array}$ & $\begin{array}{l}\text { Coverslip } \\
\text { method } \\
(\%)\end{array}$ & $\begin{array}{l}\text { Dry slide } \\
\text { method } \\
(\%)\end{array}$ \\
\hline Mean & 7.2 & 6.0 \\
\hline $\begin{array}{c}\text { Total standard devia- } \\
\text { tion .. }\end{array}$ & 3.1 & 2.4 \\
\hline Error due to observers & 2.2 & 2.2 \\
\hline Random error & 2.2 & 0.9 \\
\hline
\end{tabular}

observers made counts from six slides made at the same time from one stained drop of blood. Inaccuracy in enumeration was avoided by reducing the field to contain between ten and thirty cells. The errors due to uneven distribution on one slide was minimized by making counts not only by recording the number of reticulocytes in five hundred red cells but also by a method of inverse sampling suggested by Woolf (1948). A hundred reticulocytes were counted and the number of fields passed over before this total was reached was recorded. The number of red cells per field was calculated from a random sample of 200-300 red cells. In this way the number of reticulocytes in approximately 2,000 red cells was assessed.

From Fig. $7 b$ it will be seen that there was slightly more tendency for the values to be grouped than in the original experiment, but the variation was still large. The individual observers obtained fairly consistent results with figures ranging from 2.4 to 4.8 per cent, 3.2 to 4.2 per cent, 2.6 to 6.4 per cent, 4.1 to 6.6 per cent, 4.4 to 7.2 per-cent, and 6.4 to 9.8 per cent, but clearly the divergence of opinion between them was wide. A further study of this observer difference has shown that the number of reticulocytes seen is controlled both by the eyesight of the observer and by the magnification of the microscope used. Since this is an error that cannot readily be eliminated, the best results for clinical purposes will be obtained if the same observer makes all the counts on any one patient.

Platelet count.-The indirect and direct platelet counts, of which Dameshek's and Lempert's methods were chosen, are known to give different figures for the normal number of platelets. The indirectmethods, in which the platelets are counted in proportion to the number of red cells $\stackrel{0}{\overrightarrow{5}}$ and the total deduced from a separate red cell count, give the higher results, and therefore have $\overrightarrow{\vec{c}}$ the advantage of preserving a greater proportion of the platelets. From the techniques involved neither of these methods can be precise. In Lem- $\frac{\bar{c}}{\bar{c}}$ pert's method the error must include those due $\frac{\bar{\sigma}}{\sigma}$ to pipetting and the uneven distribution of plate- $\Omega$ lets. The minimum error of this method is likely क to exceed that of the red cell count because fewer $\overrightarrow{0}$ particles are counted. In the indirect methods the error cannot be reduced below that of counting $\vec{\omega}$ red cells, combined with the error due to uneven $\frac{\Omega}{2}$ distribution of the platelets on the slide prepara-? tions. In addition to these the scope for diver- $\overrightarrow{i r}$ gence of opinion between observers is great. is

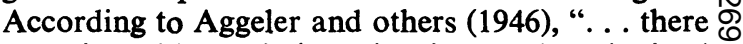
may be wide variations in the results obtained 0 by different observers, each using the same method of counting. The individual differences appear to $z$

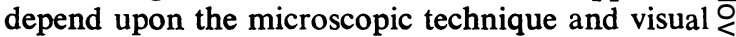
acuity of the observer. We are convinced that it $\frac{\Phi}{3}$ is impossible to standardize the platelet count so 0 that the results of even expert technicians will not $\stackrel{\mathbb{S}}{\mathrm{C}}$ show significant variation." An approximate $\vec{\theta}$ minimum error might be expected to lie between $\stackrel{\circ}{\circ}$ 10 and 15 per cent, and including an observer cors ponent the error might well be considerab greater. It is therefore rather surprising that previous estimates of error are extraordinarily small ; that calculated from Ivanitsky-Vasilenko $\frac{\circ}{\mathbb{Q}}$ and Klimova's (1937) results in the Lempert $\varrho$ method gives a random error of 0.2 per cent, $\overrightarrow{\overrightarrow{0}}$ Dameshek's figures (1932) give an error of 3.8 per cent, and Olef (1935), using an indirect method,

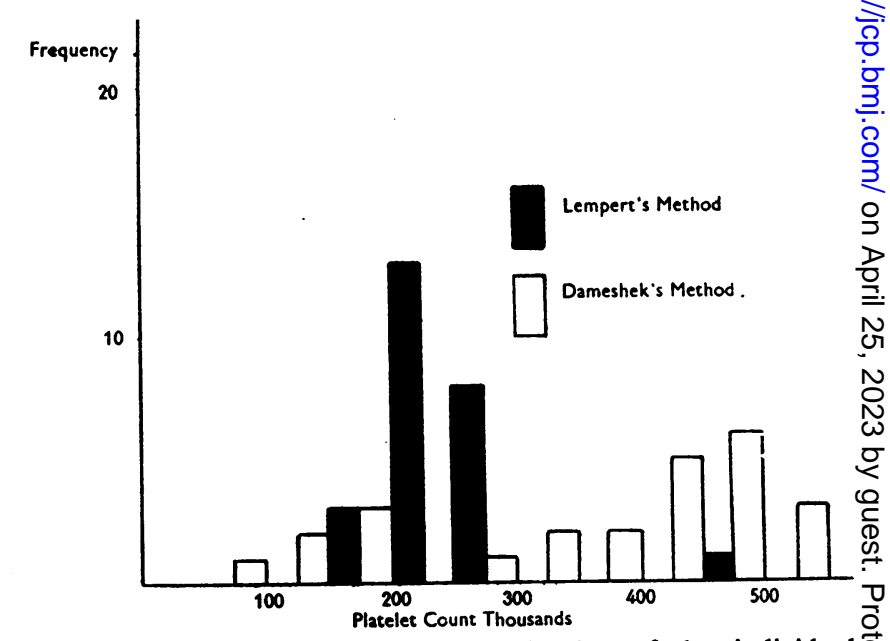

FIG. 8.- Histogram to show the distribution of the individual $\vec{\Phi}$ platelet counts by Dameshek's and Lempert's methods. 
gives figures with a coefficient of random variation of 1.8 per cent. It would seem probable that unconsc ous bias must have been responsible for these very low figures.

In this experiment five observers each made five platelet counts using five pipettes and countingchamber combinations. The counts were taken at

\section{TABLE VI}

THE COMPONENT ERRORS IN COUNTING PLATELETS EXPRESSED AS A PERCENTAGE OF THE MEAN VALUES OBTAINED BY THE TWO METHODS: THE ERRORS FOR PIPETTES AND ORDER OF TAKING THE SAMPLES ARE OMITTED BECAUSE THEY ARE SMALL IN RELATION TO THE RANDOM ERROR

\begin{tabular}{|c|c|c|}
\hline $\begin{array}{l}\text { Source of error and } \\
\text { mean value }\end{array}$ & $\begin{array}{l}\text { Dameshek's } \\
\text { method }\end{array}$ & $\begin{array}{l}\text { Lempert's } \\
\text { method }\end{array}$ \\
\hline Mean $\quad \ldots \quad \ldots$ & 365,000 c.mm. & 246,000 c.mm. \\
\hline $\begin{array}{ccc}\text { Total coefficient } & \text { of } \\
\text { variation } & . . & . . \\
\end{array}$ & $41 \%$ & $23 \%$ \\
\hline Error due to observers & $33 \%$ & $13 \%$ \\
\hline Random error & $22 \%$ & $17 \%$ \\
\hline $\begin{array}{l}\text { Random error (exclud- } \\
\text { ing one reading which } \\
\text { differed markedly } \\
\text { from the majority of } \\
\text { observations) }\end{array}$ & & $6 \%$ \\
\hline
\end{tabular}

hourly intervals from a different finger of the same subject. Thus the errors due to observers, calibration of pipettes, and counting chambers, and the time of taking the sample could all be calculated.

The distribution of the individual counts are shown in Fig. 8. Lempert's direct method shows far less variation than does the indirect method of Dameshek, and if one observation which differed markedly from the rest is excluded the random variation approaches that due to the Poisson distribution. It will be seen from Table VI that the superiority of Lempert's method follows a decrease in the difference between the counts of the five observers. In both these methods the errors attributable to the pipettes and time of taking the samples were small in comparison with those of the observers and the random variation.

These results therefore reveal errors well above the probable minimum for the method, an error which could certainly be reduced if one experienced observer made a series of counts. However, for clinical purposes great accuracy is not required and the results obtained by Lempert's method are adequate.
Whole-blood coagulation.-Pauwen and others (1942) studied the coagulation time of normal venous blood. They found that the coagulation time of different normal subjects measured as an average of four tests did not show any very great variation, but that the four tests taken at one time might differ widely. Their figures show a random variation of about 15 per cent.

In this experiment four observations of the whole blood coagulation were made by each of the three methods on one subject on ten consecutive days. In the Lee and White method the order in which the tubes were filled with blood was recorded. In the Dale and Laidlaw method the four observations were made consecutively, on the same finger, a second prick often being necessary. The order of the tests was recorded. In the capillary tubing method all the tubes were filled from the same prick. In this way differences between the methods, between the order of taking the samples, and between samples taken on different days could be estimated.

The different methods are known to give distinct values for the coagulation time. From Fig. 9 it

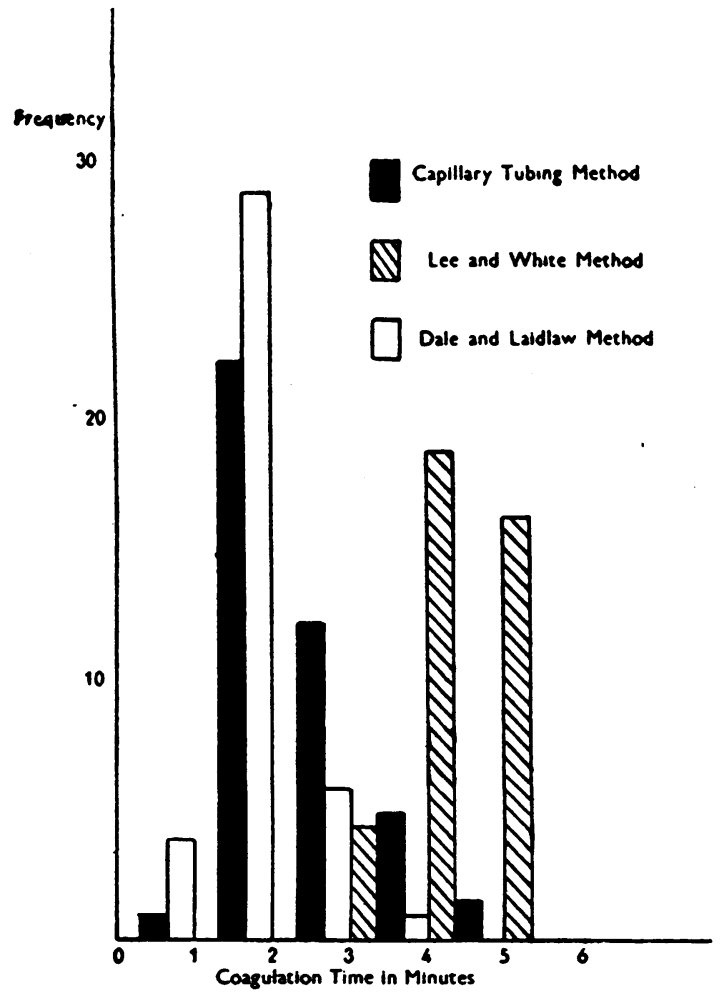

Fig. 9.- Histogram to show the distribution of individual determinations of the whole blood coagulation time by three methods. 
will be seen that the individual readings for the Lee and White and the Dale and Laidlaw methods showed approximately the same dispersion about the:r means, but since the mean value for the Dale and Laidlaw method is lower the error is relatively larger (Table VII). In the capillary tubing method

TABLE VII

THE COMPONENT ERRORS IN THE MEASUREMENT OF BLOOD COAGULATION EXPRESSED AS A PERCENTAGE OF THE MEAN VALUES

\begin{tabular}{|c|c|c|c|}
\hline $\begin{array}{l}\text { Source of error } \\
\text { and mean value }\end{array}$ & $\begin{array}{l}\text { Lee and } \\
\text { White } \\
\text { method }\end{array}$ & $\begin{array}{l}\text { Dale and } \\
\text { Laidlaw } \\
\text { method }\end{array}$ & $\begin{array}{l}\text { Capillary } \\
\text { tubing } \\
\text { method }\end{array}$ \\
\hline Mean & $4.8 \mathrm{~min}$. & $1.5 \mathrm{~min}$. & $2.0 \mathrm{~min}$. \\
\hline $\begin{array}{l}\text { Total coefficient of } \\
\text { variation for tests } \\
\text { made over a period } \\
\text { of } 10 \text { days } \quad . .\end{array}$ & $10.8 \%$ & $27.5 \%$ & $29.4 \%$ \\
\hline $\begin{array}{l}\text { Total coefficient of } \\
\text { variation for tests } \\
\text { made on one day }\end{array}$ & $4.7 \%$ & $15.5 \%$ & $14.0 \%$ \\
\hline $\begin{array}{l}\text { Error due to the } \\
\text { order of taking } \\
\text { samples on one day }\end{array}$ & $6.2 \%$ & $20.9 \%$ & 0 \\
\hline $\begin{array}{l}\text { Error due to varia- } \\
\text { tions between the } \\
\text { different days on } \\
\text { which samples were } \\
\text { taken }\end{array}$ & $9.7 \%$ & $22.5 \%$ & $25.9 \%$ \\
\hline Random error & $7.0 \%$ & $25.1 \%$ & $28.0 \%$ \\
\hline
\end{tabular}

the variation was greater. From an analysis of the constituent errors it was seen that both the methods using capillary blood showed a greater change from day to day than did the method of Lee and White. The Dale and Laidlaw method also showed a big discrepancy between the tests taken at one time, and from Table VIII it will be seen that the first test had a longer coagulation time. From the method of taking the samples this was probably due to a larger amount of tissue juice in tests after the first. In the Lee and White method the first tube often coagulated more quickly than the others, and presumably thromboplastin from the needle was included in this specimen.

These results illustrate the small variability of the coagulation time as tested by the Lee and White method. The technique appears to be more reliable than that of Pauwen and others (1942).

Red cell fragility.-Many of the factors which influence the red cell fragility curve, including the degree of anaemia, oxygenation of the blood, the $p \mathrm{H}$ of the saline solutions, and the temperature of incubation, have been worked out by Dacie and Vaughan (1938). They used a technique in which all these factors were considered to determine the red cell fragility in fifty normal subjects, and thus set limits to the normal range. Since discrepancies between the results of different observers have arisen in relatively simple methods, it seemed is possible that the red cell fragility curve, as used $\vec{D}$ in a routine laboratory, might show a wider range of variation in normal people than was recorded by the originators of the technique.

\section{TABLE VIII}

A COMPARISON OF THE MEAN VALUES FOR FOUR CONSECUTIVE ESTIMATIONS OF BLOOD COAGULATION MADE BY THREE DIFFERENT METHODS (THE FIGURES GIVEN ARE THE AVERAGES OF THE VALUES OBTAINED ON TEN DIFFERENT DAYS)

\begin{tabular}{c|c|c|c|c}
\hline \multirow{2}{*}{ Method } & \multicolumn{3}{|c}{ Order of test } \\
\cline { 2 - 5 } & 1 & 2 & 3 & 4 \\
\hline Lee and White & $4.4 \mathrm{~min}$. & $4.8 \mathrm{~min}$. & $5.1 \mathrm{~min}$. & $5.0 \mathrm{~min}$. \\
\hline Dale and Laidlaw & $2.04 \mathrm{~min}$. & $1.38 \mathrm{~min}$ & $1.32 \mathrm{~min}$. & $1.40 \mathrm{~min}$ \\
\hline Capillary tubing & $1.92 \mathrm{~min}$ & $2.12 \mathrm{~min}$ & $2.05 \mathrm{~min}$. & $2.10 \mathrm{~min}$ \\
\hline
\end{tabular}

In this experiment, therefore, five observers measured the red cell fragility in fifty normal subjects. Ten observations were made by each of three observers from one laboratory, and twenty by two observers from a second laboratory. The same saline solutions were used throughout. In most cases duplicate tubes were set up to reduce the errors of pipetting. In addition the red cell fragility of one normal subject was tested on several different days.

The mean value for the median corpuscular fragility, 0.392 per cent, was higher than that of Dacie and Vaughan (1938), 0.366 per cent, because less blood was used in proportion to the volume of saline. The readings of the five observers, considered separately, showed variation in relation to their respective mean values which was comparable to that of Dacie and Vaughan (1938), but, since the observers' mean values were different, the total range was wider (Fig. 10). Thus, if the red cell fragility is always measured by one observer a range of variation comparable to that established by Dacie and Vaughan will include all the readings on normal people. On the other hand, if the test is made by a number of observers wider limits of normality must be set. The diversity of the red cell fragility curve in one normal subject 


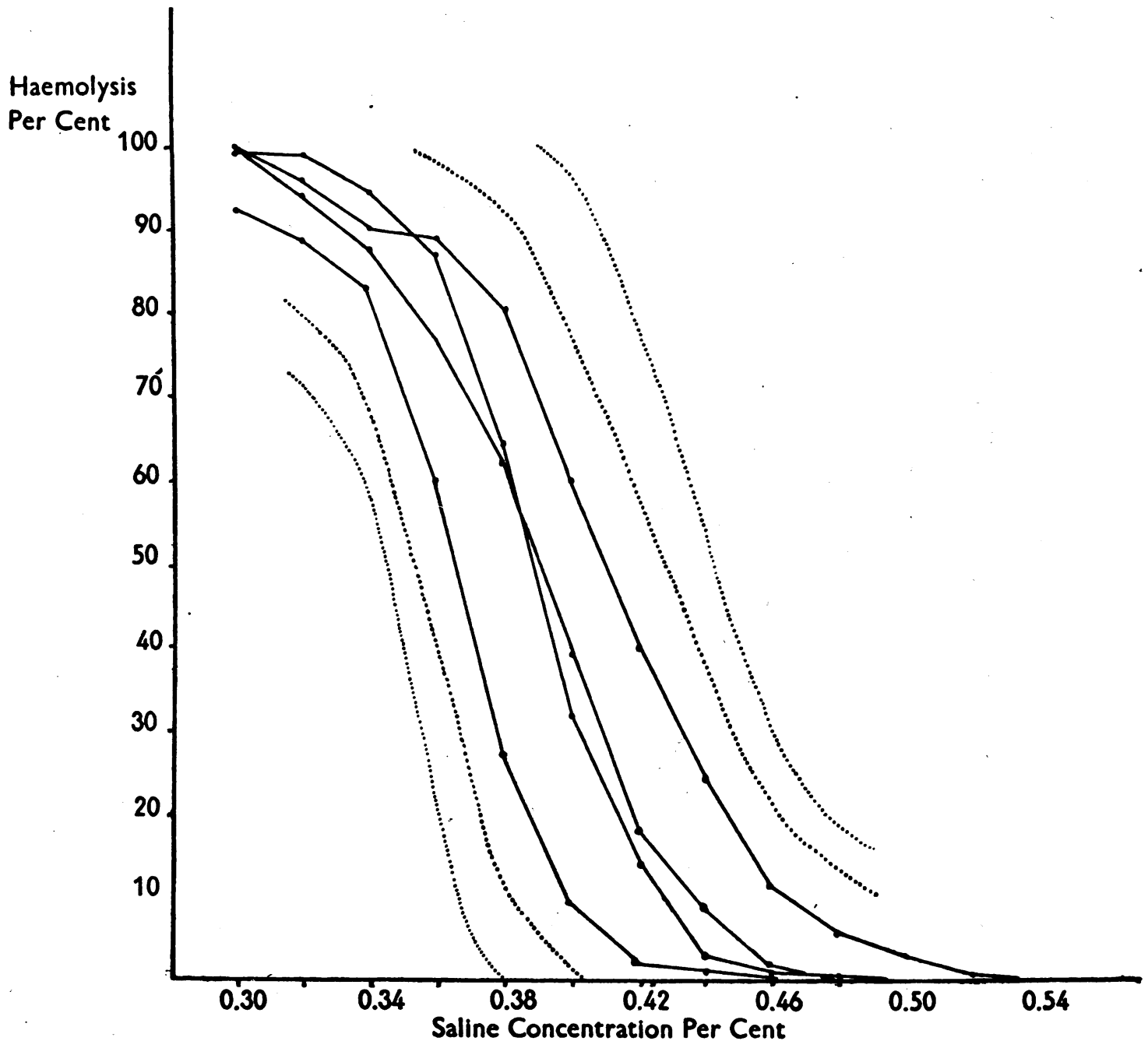

FIG. 10.-Diagram to show the mean values for the red cell fragility curve in normal people obtained by different observers (continuous lines). The limits of probable variation referred to in the text are shown by discontinuous lines.

(Fig. 11) also suggests that it would be unwise to accept a narrow concept of abnormality.

In Fig. 10 the mean values for the four sets of observations are given; above and below these are indicated two limits of the probable variation in normal people. The narrower range represents one standard deviation above and below the means of the more extreme observers. These limits should include nearly 90 per cent of all the readings. The wider limits represent two standard deviations above and below the extreme observers, and these should include almost all normal fragility curves.

\section{Discussion}

In all these investigations emphasis has been placed on the use of a particular method as a routine procedure. We have therefore deliberately not required the observers to have specialized skill in any one technique. It may well be thought that the large errors obtained, in most cases larger than any previously recorded, are proof that none but those highly skilled can carry out these investigations adequately. To some extent this is true, for many of the techniques can be used with far greater precision. The Haldane method for haemoglobin estimation, for example, a notoriously 
unreliable method in routine practice, can give very uniform results in the hands of one observer (Macfarlane, 1945). Again, several of the observers taking part in these experiments made reticulocyte counts on one sample of blood which showed very little variation, and Price-Jones (1933) and Mogensen (1938) have demonstrated the high precision of the Price-Jones curve. Though one skilled worker may obtain very uniform results it does not follow that the figures of different skilled observers will agree. In the Haldane haemoglobin estimation, for example, Macfarlane (1945) has shown that the skilled observers almost invariably disagreed; in this experiment the reticulocyte counts of the different observers varied, and a similar observation was made by Aggeler and others (1946) in counting platelets.

From this it is clear that, were it possible for one observer to carry out all the investigations, the variability of the results should approximate to the minimum error of the method. The probable minimum error's of some of the methods discussed

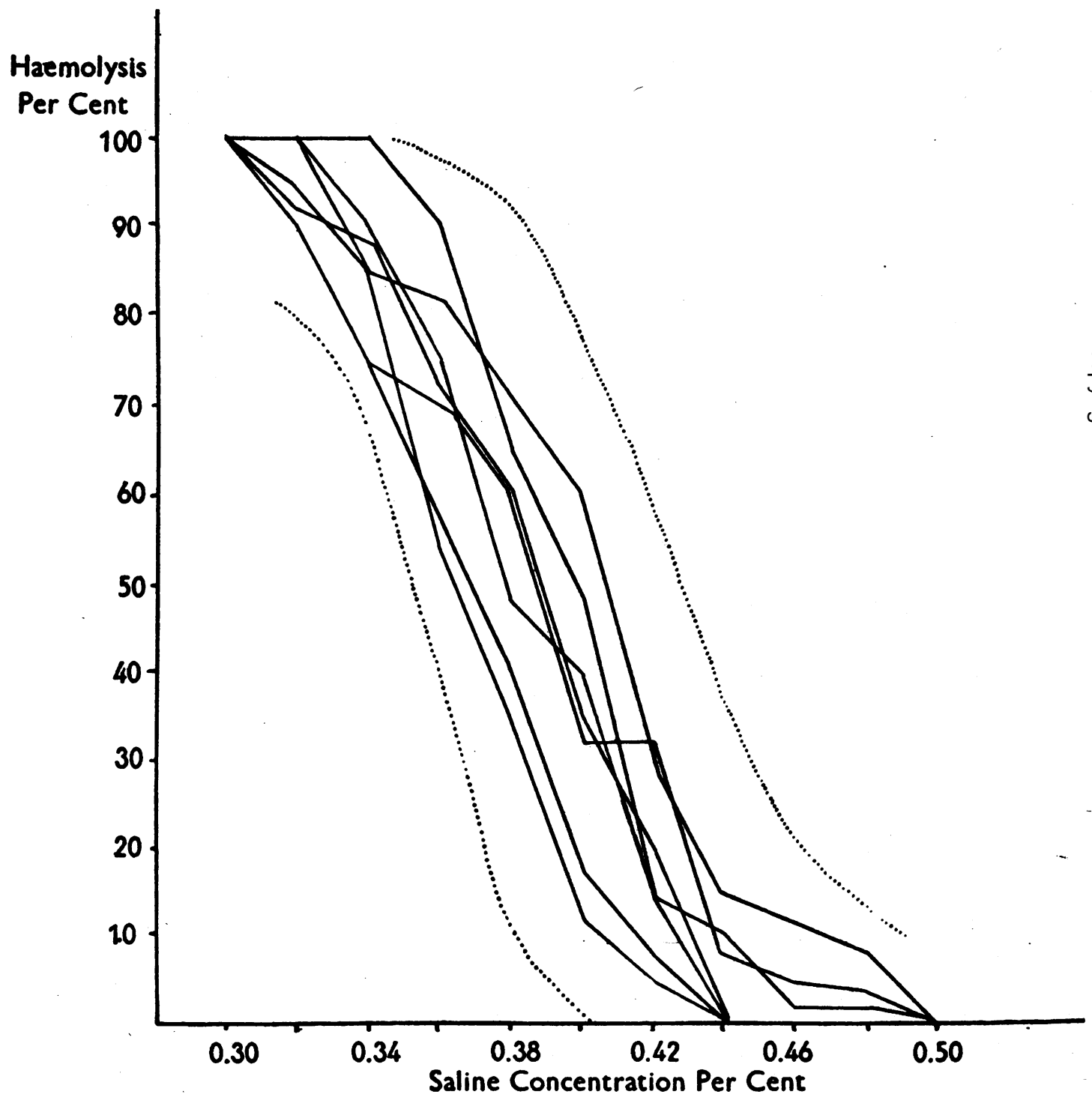

Fro. 11.-Diagram to show the range of variation in the red cell fragility curve in one normal subject. 
EXTENT OF ERROR: PER CENT HAEMOGLOBIN

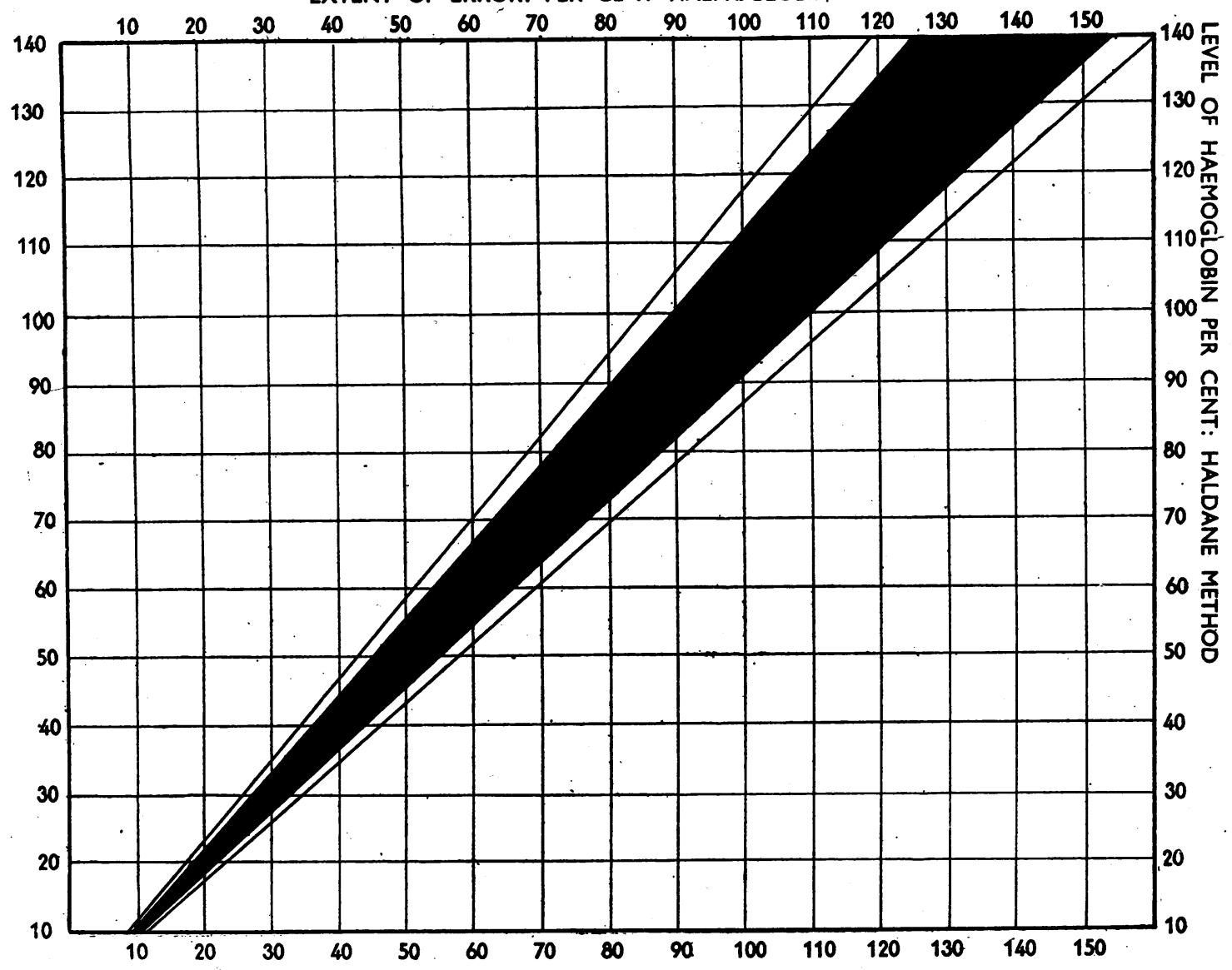

Fig. 12.-Diagram to show the error of haemoglobin determination by the Haldane method at levels of haemoglobin from 10 to 140 per cent. On the vertical axes the magnitude of the error is indicated. The solid area represents the range within which nineteen out of twenty repeated estimations on one sample will fall. The outer lines give the upper and lower limits that might be expected to contain nineteen out of twenty pairs of estimations on the same blood sample. In any two estimations on the same patient, therefore, a difference greater than these limits would have to be obtained before any significant change in haemoglobin could be inferred. The value is referred to as "the significant difference." The values for significant difference in Figs. 12, 13, and 14 are approximations because the error for an increase in the value is slightly different from that of a decrease. (The error should be calculated from $2 \sqrt{+S_{2}{ }^{2}}$ for any given difference and is in fact calculated from $2 \sqrt{s_{1}{ }^{2}}$ at the upper level and $2 \sqrt{s_{2}}$ at the lower level.)

Example of the Use of Fig. 12: If the haemoglobin is recorded as 70 per cent (vertical axis) repeated observations would be expected to lie between 63 and 76 per cent (horizontal axis). If the haemoglobin is 70 per cent on one occasion, a second observation must exceed 81 per cent or fall below 59 per cent before any significant change can be inferred.

are given in Table I. These limits are important, for it is common for skilled observers to improve on them. In the red cell count, for example, any skilled technician can, as Wintrobe has said, obtain results on one sample of blood that will agree within 200,000 cells. Again some of the recorded figures for platelet counting show the most extraordinary agreement (Olef, 1935; Ivanitsky-
Vasilenko and Kilmova, 1937). This uniformity, which would be impossible for a mechanically impartial recorder, is the result of an unconscious bias which was clearly demonstrated by Macfarlane (1945) in the case of the Haldane haemoglobin determinations. Macfarlane showed that observers could use this method with a greater uniformity of results when provided with 
graduated tubes than when only plain tubes were supplied. In the case of the red cell count this excessive accuracy can be shown to decrease, rather than increase the reliability of the results (Biggs and MacMillan, 1948).

The question of importance is the course which should be followed in a routine laboratory. 'Investigations of which fifty to a hundred may be made in one day cannot all be made by one highly skilled observer. With these, it is essential to select those methods which give reasonably good results in the hands of the "average" observer. The methods of most importance are those which assess the degree of anaemia and the response to treatment. The selection of the method for haemoglobin estimation is clearly important and, as Macfarlane and others (1948) have shown, the methods with an error approaching the minimum are the neutral grey photometer using oxyhaemo- globin, the Sahli-Zeiss comparator using acid haematin, and the Duboscq photometer using various pigments. In addition, the haematocrit gives very reliable results and from these two observations the mean corpuscular haemoglobin concentration may be calculated. These measurements, together with the pathologist's opinion on the appearance of the blood film, give the best information available for routine diagnosis except in the macrocytic anaemias, where some assessment of cell size is necessary.

The mean corpuscular volume and colour index are at present routine procedures in all haematological laboratories, where their vagaries give rise to constant irritation. The labour involved by these measurements is, in our opinion, not justified by the results which they give. There are few pathologists who would accept the figures recorded by either of these indices if they were not borne

EXTENT OF ERROR: PER CENT HAEMOGLOBIN

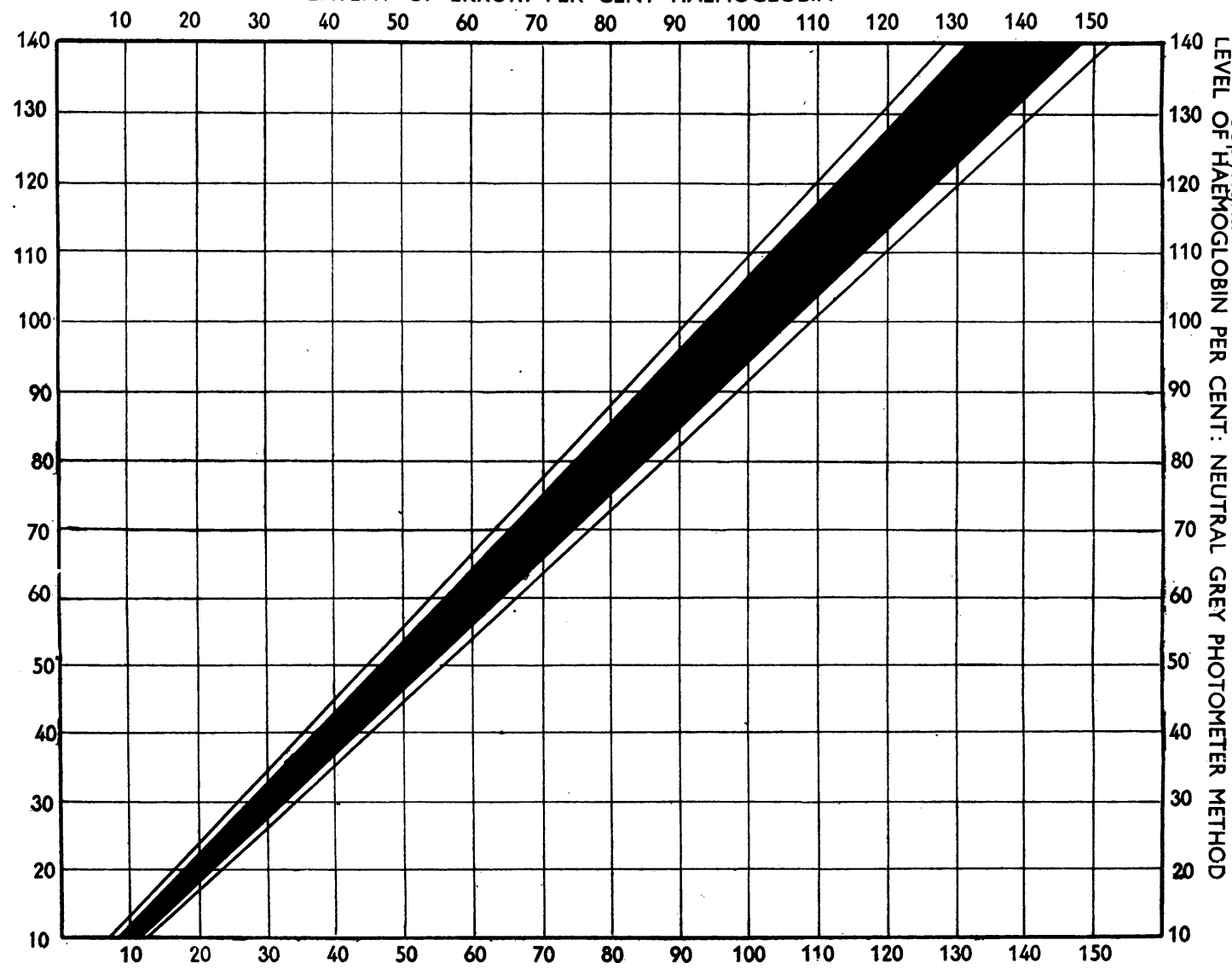

FIG. 13.-Diagram to show the error of haemoglobin determination by the neutral grey photometer method for levels of haemoglobin from 10 to 140 per cent (see legend to Fig. 12). 


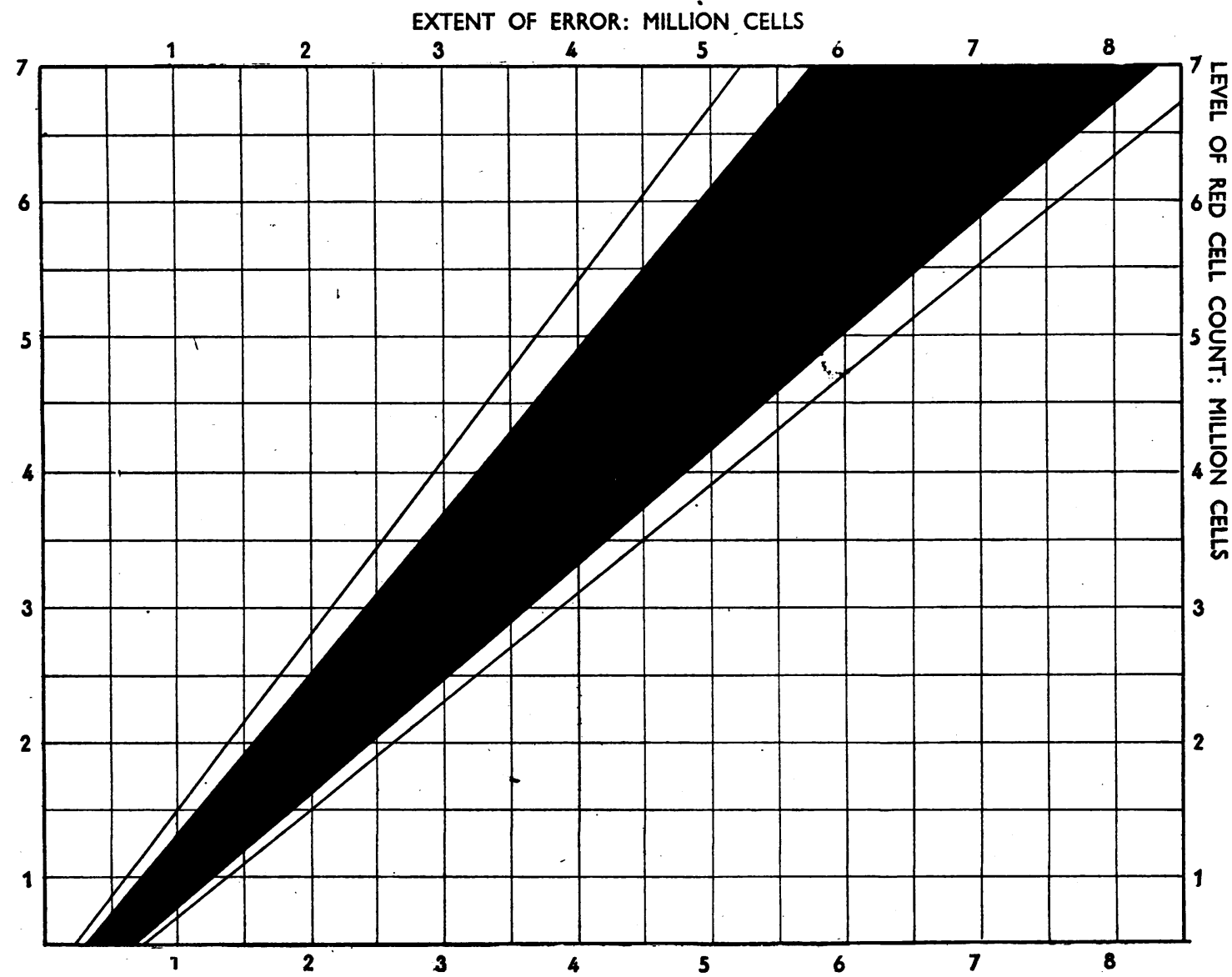

Fig. 14.-Diagram to show the error of the red cell count for counts varying from 50,000 to $7,000,000$ using a 1/200 dilution of blood, and counting of eighty small squares in a Neubauer counting chamber (see legend to Fig. 12).

out by the appearance of the blood film. This fact in itself illustrates a conscious or unconscious conviction that the figures are not reliable, a conviction well supported by these investigations. The only exception which must be made is in the case of macrocytic anaemia in laboratories where the drawing of a Price-Jones curve is difficult. In these cases repeated observations will give a broad general impression of the ti end of cell size.

In the case of the reticulocyte count, where despite all care different skilled observers tend to disagree, the simple procedure of encouraging one observer to make all the counts on any one patient will increase the reliability of that patient's record.

In the case of investigations less frequently carried out, two possibilities exist. Single observers may be trained to attain specialized skill until their errors approach the minimum for the $\mathrm{x}$ method. Alternatively, the techniques may be carried out by a number of competent observers, when the range of their errors will be comparable to those recorded here. If the special investigation is complicated and the results require to be accurate, as for example in prothrombin determinations, the former procedure is preferable. On the other hand, many of the investigations need not be measured with very great precision for ordinary clinical purposes, and the results of the "average observer" are probably adequate. It would seem to us preferable to have a laboratory staffed by workers competent to carry out any investigation that could reasonably be requested, than a staff of specialists in single techniques.

The final problem is the application of these concepts of error to routine practice. The errors that we have calculated in most cases apply only 
to the readings recorded. The error of haemoglobin determination by the Haldane method, for example, is relative to the level of haemoglobin. Thus an absolute error of 5.2 per cent at 100 per cent haemoglobin is reduced to 2.6 per cent at 50 per cent. The alteration in error with change in haemoglobin level is shown in Fig. 12. This diagram shows the range within which repeated observations on one sample may be expected to fall (solid area), and the difference between two haemoglobin readings which may be considered significant. In this method doubling the volume of bood used for low concentrations of haemoglobin would be expected to give little increased accuracy and must introduce additional error from the filling of pipettes on two occasions.

In the neutral grey photometer method the error of reading the photometer remains constant and though this error is small it becomes relatively more important at low levels of haemoglobin. Thus a slight reduction in error will result from doubling the amount of blood when the haemoglobin reading is less than 30 per cent. The errors of this method are shown in Fig. 13.

In the red cell count, as Berkson and others (1940) have shown, the error tends to increase with a decrease in the number of ce.ls counted. Fig. 14 shows the errors that will occur with a constant technique of counting eighty small squares in a dilution of 1/200 using a Neubauer counting chamber. Some increase in precision will follow an increase in the number of cells counted. Using the technique outlined above, a count of one million cells will have an error of 12.6 per cent. By using a dilution of $1 / 100$ and counting 160 small squares the error may be reduced to 9.5 per cent. Further reduction in error can be obtained by using two pipettes and two counting chambers. In the example given above the error would in this way be reduced to 7.8 per cent if a total of four hundred cells were counted (eighty small squares from each counting chamber using a dilution of $1 / 100$ ).

The random error of the haematocrit is probably independent of the level of packed cells and thus will be proportionately greater at low haemotocrit readings. However, this error is sufficiently small to be negligible in comparison with the errors of other methods in use.

When reticulocyte counts are made by many different observers, the errors are so large that no useful limits of probable variation can be set. In the hands of one reasonably skilled observer the error approaches that of the binominal distribution. The limits of error for counts of five hundred and a thousand cells are shown in Table IX.
TABLE IX

THE ERROR IN ESTIMATING THE PERCENTAGE OF RETICULOCYTES WHEN ONE COMPETENT OBSERVER COUNTS 500 OR 1,000 RED CELLS WITH DIFFERENT PROPORTIONS OF RETICULOCYTES

\begin{tabular}{|c|c|c|c|c|}
\hline \multirow[t]{2}{*}{$\begin{array}{l}\text { Percentage } \\
\text { of } \\
\text { reticulocytes }\end{array}$} & \multicolumn{2}{|c|}{$\begin{array}{l}\text { Range within which } \\
\text { the percentage of } \\
\text { reticulocytes should } \\
\text { fall is } 19 / 20 \text { re- } \\
\text { peated counts on } \\
\text { one sample }\end{array}$} & \multicolumn{2}{|c|}{$\begin{array}{l}\text { Significant differ- } \\
\text { ence in percentage } \\
\text { of reticulocytes }\end{array}$} \\
\hline & 500 cells* & 1000 cells $\dagger$ & 500 cells* & 1000 cells* \\
\hline $\begin{array}{r}1 \\
2 \\
3 \\
4 \\
5 \\
6 \\
7 \\
8 \\
9 \\
10 \\
15 \\
20 \\
25 \\
30 \\
35 \\
40 \\
45 \\
50\end{array}$ & $\begin{array}{c}0-2 \\
1-3 \\
1-5 \\
2-6 \\
3-7 \\
4-8 \\
5-9 \\
6-10 \\
6-12 \\
7-13 \\
12-18 \\
17-23 \\
21-29 \\
26-34 \\
31-39 \\
36-44 \\
41-49 \\
46-54\end{array}$ & $\begin{array}{c}0-2 \\
1-3 \\
2-4 \\
3-5 \\
4-7 \\
5-8 \\
6-9 \\
6-10 \\
7-11 \\
8-12 \\
13-17 \\
18-23 \\
22-28 \\
27-33 \\
32-38 \\
37-43 \\
42-48 \\
47-53\end{array}$ & $\begin{array}{l}1.5 \\
2.0 \\
2.0 \\
2.5 \\
3.0 \\
3.0 \\
3.0 \\
3.5 \\
3.5 \\
4.0 \\
4.0 \\
5.0 \\
5.5 \\
6.0 \\
6.0 \\
6.0 \\
6.5 \\
6.5\end{array}$ & 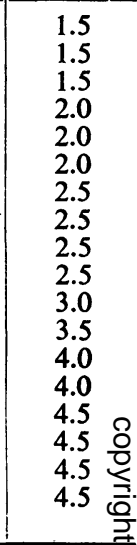 \\
\hline
\end{tabular}

* Calculated from the standard deviation.

In platelet counting the error is so large that $\stackrel{2}{\overrightarrow{7}}$ only conspicuous and progressive changes should $\bar{\partial}$ be considered significant.

\section{Summary}

1. A series of experiments was devised to? assess the errors inherent in the routine use of some $\frac{\text { o }}{3}$ common haematological methods. The results are summarized in Table I and in the figures illustra- $\frac{O}{3}$ ting the text.

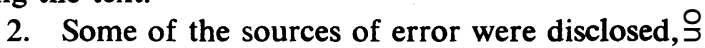
and among these disagreement between observers $?$ was important.

3. An increase in the reliability of routine work N will follow the selection of those methods which give the best results in the hands of the average 0
laboratory worker.

4. In the diagnosis of anaemia the most precise measurements found in this investigation were: haemoglobin determination using oxyhaemoglobin $\Phi$ and a neutral grey photometer, the haematocrit, + the mean corpuscular haemoglobin concentration, $\frac{0}{O}$ and the mean cell diameter derived from the Price- $\frac{\vec{D}}{\mathbb{D}}$ Jones curve. 
5. The red cell count has an error of 9 per cent and thus the colour index and mean corpuscular volume are too variable to record the small differences of interest to the clinician. The routine use of these indices might be restricted to the study of macrocytic anaemia in laboratories where a Price-Jones apparatus is not available.

6. The most important error in counting reticulocytes arises from disagreement between observers; this will be minimized if the same laboratory worker makes all the counts on any one patient.

7. The platelet count by both Dameshek's and Lempert's methods showed a large standard deviation, but Lempert's method was preferable.

8. Five observers recorded different mean values for the red cell fragility in normal people. In the routine laboratory it would be wise to use a wider concept of normality than that established by Dacie and Vaughan (1938).

We thank the many doctors and laboratory technicians who willingly took part in these experiments. The statistical analysis of the Price-Jones curve and the red cell fragility curve were made by Mr. Finney, whom we also thank for assistance and advice in all the mathematical difficulties that arose. We should like to thank Dr. R. G. Macfarlane for his continued interest and help throughout the investigation.

\section{REFERENCES}

Aggeler, P. M., Howard, J., and Lucia, S. P. (1946). Blood, $1,472$. Berkson, J., Magath, T. B., and Hurn, M. (1935). J. Amer. stat. Ass., 30, 414 .

Berkson, J., Magath, T. B., and Hurn, M. (1940). Amer. J. Physiol. 128, 309.

Biggs, R., and MacMillan, R. L. (1948). J. clin. Path., 1, 288.

Dacie, J. V., and Vaughan, J. M. (1938). J. Path. Bact., 46, 341.

Dale, H. H., and Laidlaw, P. P. (1911-12). J. Path. Bact., 16, 351.

Dameshek, W. (1932). Arch. intern. Med., 50, 579.

Duffie, D. H. (1945). Amer. J. clin. Path., 15, Tech. Sect., p. 27.

Humble, J. G., and Belyavin, G. (1948). J. clin. Path., 1, 77.

Humble, J. G., and Belyavin, G. (1948). J. clin. Path., 11, Arch. int. Pharmacodyn., 55, 365.

Jacobsen, E., Plum, C. M., and Rasch, G. (1947). Acta path. nicrobiol. scand., $24,554$.

King, E. J., Gilchrist, M., Wootton, I. D. P., Donaldson, R., Sisson, R. B., Macfarlane, R. G., Jope, H. M., O'Brien, J. R. P., Peterson J. M., and Strangeways, D. H. (1947). Lancet, 2, 789.

Lee, R. I., and White, P. D. (1913). Amer. J. med. Sci., 145, 495.

Lempert, H. (1935). Lancet, $1,151$.

Macfarlane, R. G. (1945). Med. res. Coun. Rep., No. 252, p. 59, London.

Macfarlane, R. G., King, E. J., Wootton, I. D. P., and Gilchrist, M. (1948). Lancet, 1, 282

Miller, A. T. (1938-39). J. Lab. clin. Med., $24,547$.

Mogensen, E. (1938). "Studies on the size of the Red Blood Cells especially in some Anaemias." Oxford University Press.

Olef, I. (1935). J. Lab. clin. Med., 20, 416.

Osgood, E. E. (1935). Arch. intern. Med., 56, 849.

Pauwen, L. J., Roskam, J., and Swalue, L.'(1942). 'Arch. int. Pharmacodyn., 68, 239.

Plum, C. M. (1942). Acta physiol. scand., 4, 259.

Price-Jones, C. (1933). "Red Blood Cell Diameters." Oxford University Press.

Price-Jones, C., Vaughan, J. M., and Goddard, H. M. (1935). J. Path. Bact., 40, 503

Sabrazes, J. (1904). Folia haemat., 1, 394

Snedecor, G. W. (1946). "Statistical Methods," p. 4. Iowa State College Press.

Wintrobe, M. M. (1931-2). J. Lab. clin. Med., 17, 899.

Wintrobe, M. M. (1931-2). J. Lab. clin. Med., 17, 899.
Wintrobe, M. M. (1934). Arch. intern. Med., B4, 256.

Wintrobe, M. M. (1946). “Clinical Haematology," p. 253. London: Henry Kimpton.

Woolf, B. (1948). Nature, Lond., 161, 361. 